\title{
Health Promotion Activities in Bandung Public Health Centre (Puskesmas)
}

\author{
Siti Fairuz Nadya, ${ }^{1}$ Insi Farisa Desy Arya, ${ }^{2}$ Anggraini Alam ${ }^{3}$ \\ ${ }^{1}$ Faculty of Medicine Universitas Padjadjaran, ${ }^{2}$ Department of Public Health Faculty of \\ Medicine Universitas Padjadjaran, ${ }^{3}$ Department of Child Health Faculty of Medicine Universitas \\ Padjadjaran/Dr. Hasan Sadikin General Hospital Bandung
}

\begin{abstract}
Background: Health promotion is one of Public Health Centre (Pusat Kesehatan Masyarakat, Puskesmas) essential health effort able to increase community health status. The purpose of this study was to describe health promotion activities in Bandung Public Health Centre (Puskesmas).

Methods: This study was a cross sectional descriptive study using questionnaire as data collection instrument. The questionnaires were distributed to 24 Puskesmas in Bandung that were selected randomly using simple random sampling method. The process of questionnaire filling was performed by health promotion officer after informed consent was done. The variables were basic health promotion strategies, health promotion supports, health promotion in health facility and health promotion in community.

Results: Most of the Puskesmas showed that basic health promotion strategies, health promotion in health facility and health promotion in community were already done. Support media that was mostly used was printed media while lectures was the most used method. Human resources practitioner and coordinator of health promotion were dominated by mid level health workers consists of midwife and nurse. This study showed that the majority of health promotion coordinator had underwint training and certificate related to health promotion. The availability of funds were possessed by 13 out of 24 sample. While, health promotion guideline were possessed by less than half of the sample.

Conclusions: Health promotion is done in almost all sample. There is lack of health promotion support in the form of the availability of funds and guideline of health promotion method. [AMJ.2016;3(3):460-8]
\end{abstract}

Keywords: Health promotion, health promotion support, Puskesmas

\section{Introduction}

Public Health Centre (Pusat Kesehatan Masyarakat, Puskesmas) is the executive unit of a municipal (city or regency) health office which holds the primary role for providing health services, particularly stressing on promotive and preventive aspects. Puskesmas is responsible for both essential and developmental health services. Health promotion is an example of the former group able to contribute to increase the public level of health. According to WHO, health promotion is a process of increasing an individual's capabilities to improve health. ${ }^{1-3}$

In 1980, an innovation known as "Quit Campaign" was introduced in Australia and it was a nationwide campaign aiming to reduce smoking-related mortality. The campaign reduced the prevalence of smoking from $40 \%$ in 1983 to $15.9 \%$ in 2010 among adult men. It is thus implicitly concluded that health promotion leads to the improving of public health status. Another example from Australia also demonstrates that innovations in health promotion leads to fewer interventions on teenagers with cigarette and alcohol abuse. ${ }^{5}$

In Indonesia, the success of health promotion leads to clean and healthy behaviors (Perilaku Hidup Bersih dan Sehat, PHBS) in public. In Bandung's 2011 health profile, $65.64 \%$ households were reported to practise the behavior but interestingly there was no yearly increasing in the percentage of households practising such behavior. ${ }^{6,7}$

Indonesia has adopted the nationwide health insurance (JKN) per 1 January 2014. According to Regulation of the President of the Republic of Indonesia number 12 year 2013 on the nationwide health insurance,

Correspondence: Siti Fairuz Nadya, Faculty of Medicine, Universitas Padjadjaran, Jalan Raya Bandung-Sumedang Km.21, Jatinangor, Sumedang, Indonesia, Phone: 085316488993 Email: fairuz.nadya@gmail.com 
every citizen is entitled to (1) primary level healthcare, consisting of general health care, (2) advanced level healthcare based on referrals and (3) other forms of health care as laid out by the Minister of Health. Promotive and preventive efforts form the bulk of primary level healthcare. Additionally, the nationwide health insurance adopts a system of capitation based on the number of applicants regarding to the type and number of provided healthcare services. In order to prevent medical personnels defaulting on the capitation fees, health promotion becomes top priority in an attempt to curb down costs on curative efforts. ${ }^{8}$

Therefore, this study on the degree of health promotion done by various Puskesmas in Bandung in 2011 should help us to face the era of nationwide health insurance with its own set of demands on health promotion, challenges on managing the limited capitation fees and the relatively stagnant adoption of clean and healthy behavior by the people. The purpose of this study was to describe health promotion activities in Bandung Public Health Centre.

\section{Methods}

This was a cross-sectional descriptive study which employed a simple randomized sampling method by choosing 24 out of 73 Puskesmas in Bandung. Data collection were carried out from September to November 2014.

This study had been approved by Health Research Ethics Committee of Faculty of Medicine of Universitas Padjadjaran. Primary data were recorded using validated questionnaires based on the standardized protocol on health promotion in Puskesmas published by the Ministry of Health Republic of Indonesia. The questionnaires contained questions on health promotion strategies in Indonesia, supportive measures of such strategies, and health promotive activites both on healthcare centre premises and in the community. The questionnaires were self-administered by 24 officers from the aforementioned 24 Puskesmas.

Informed consent was collected by the healthcare officers prior to filling out of the questionnaires. The same officers also filled out another informed consent form stating their willingness to participate in this study. Respondents with incomplete questionnaires were later contacted. Data analysis were carried out using Microsoft Excel 2010.

\section{Results}

Data were collected from 24 Puskesmas in Bandung. Four variables in this study and the results for the first variable which was basic strategies of health promotion are presented in Table 1.

From four facets of basic strategy, optimising the environment was practised the least. Additionally, the questionnaires revealed that not all of the primary health Centres exercised all four strategies and there were Centres practicing none.

Table 2 demonstrated that midwives contributed the most in the implementation of basic health promotional strategies while community health officers contributed the least. The public formed the main target when it came to empowerment and optimisation of the environment. Public organizations were at the last of advocacy. There was not primary healthcare Centres picked political organizations as their targets of advocacy. In the meantime, partnerships with religious elders were commonly practised. Empowerment and optimisation of the environment were done mostly on a monthly basis.

On the second variable, i.e. health promotion supportive instruments, there were 5 investigated subvariables. Table 3 demonstrated that 6 Puskesmas utilized the guideline-directed individual, group and masstargeted approaches. Mass media also formed the most widely utilized health promotion instrument.

Out of 24 Puskesmas, 13 had enough funds to carry out health promotional programs

Table 1 Basic Strategies of Health Promotion

\begin{tabular}{lc}
\hline \multicolumn{1}{c}{ Basic Strategy } & Frequency \\
\hline Empowerment & 21 \\
Environment Optimisation & 18 \\
Advocacy & 19 \\
Partnership & 22 \\
\hline
\end{tabular}


Table 2 Basic Strategies of Health Promotion and Their Implementation

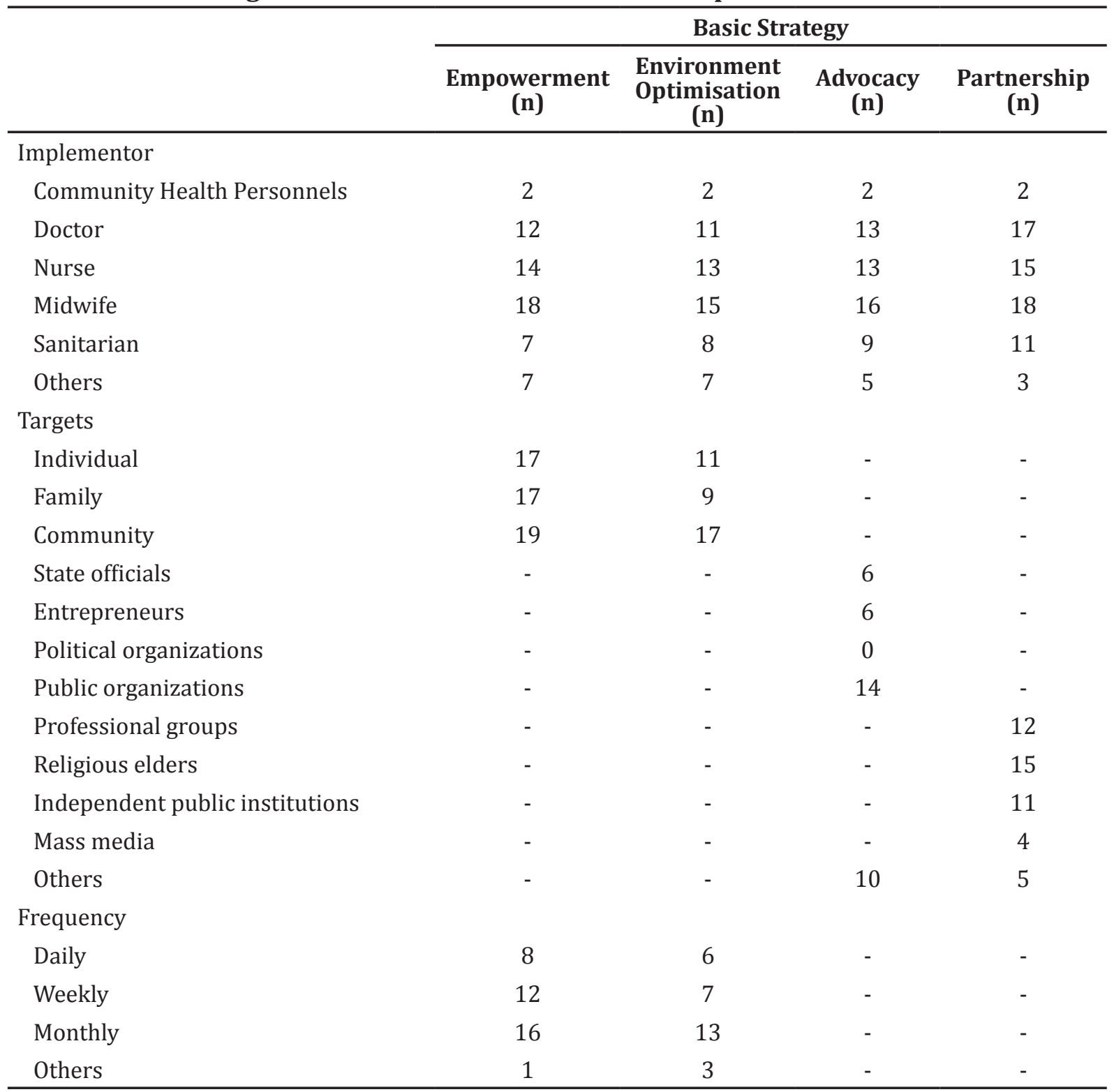

and 10 had a midwife(s) to coordinate such programs. Over half of study samples had a health promotional efforts coordinator who had undergone training and gained certification.

Table 4 demonstrated that health promotion in the inpatient wards was the least in number among all forms of health promotion within the healthcare premises.

Table 5 showed that approaches to individuals and families formed the bulk of health promotion in the community. All types of health personnels contributed to these approaches with doctors, nurses and midwives contributing the most.

\section{Discussion}

As demonstrated in table 1, more than half of the participating healthcare Centres (Puskesmas) had performed the basic strategies of health promotion. A study conducted by Rezeki and Mulyadi ${ }^{10}$ in Puskesmas Sei Kijang, Pelalawan Regency demonstrated a significant association between health promotional strategies, i.e. advocacy, empowerment and optimisation of environment, and the adoption of clean and healthy behaviors (Perilaku 
Siti Fairuz Nadya, Insi Farisa Desy Arya, Anggraini Alam: Health Promotion Activities in Bandung Public 463 Health Centre (Puskesmas)

Table 3 Health Promotion Supportive Instruments (1)

Supportive Instruments

Number

Method

Individual approach

Health education 23

Counselling 20

$\begin{array}{ll}\text { Others } & 0\end{array}$

Group Approach

Lectures 20

Seminar 5

Group Discussions $\quad 15$

Snow-ball 0

Buzz Group 11

Simulations $\quad 2$

Role Play $\quad 2$

Others 0

Mass Approach

Lectures $\quad 19$

Talkshows 9

Simulation $\quad 9$

Films $\quad 4$

Articles in the media $\quad 3$

Billboard 17

Others 1

Media

Printed 7

Booklet 21

Leaflet 12

Flyer $\quad 17$

$\begin{array}{lr}\text { Flipchart } & 6\end{array}$

Rubric 20

$\begin{array}{ll}\text { Poster } & 18\end{array}$

Photos 3

Others 0

No assisting material

$\begin{array}{ll}\text { Electronic } & 7\end{array}$

Television 3

Radio 1

$\begin{array}{ll}\text { Video } & 13\end{array}$

Slides $\quad 2$

Film Strip $\quad 1$ 
Table 3 Health Promotion Supportive Instruments (2)

\begin{tabular}{lc}
\hline \multicolumn{1}{c}{ Supportive Instruments } & Number \\
\hline Others & 2 \\
No assisting material & 0 \\
Media Boards & 9 \\
Billboard & 3 \\
Others & 0 \\
No assisting material & 6 \\
Guideline & 13 \\
Funds & \\
Human Resources Coordinators & 3 \\
Community health personnels & 2 \\
Doctor & 10 \\
Midwife & 5 \\
Nurse & \\
Human Resources Coordinators & 0 \\
Sanitarian & 4 \\
Others & \\
Qualitifcations & \\
D1 & 2 \\
D3 & 17 \\
S1 & 3 \\
Professional & 2 \\
Training & 23 \\
Certification & 16 \\
\hline & \\
\hline
\end{tabular}

Hidup Bersih dan Sehat, PHBS). Even though more than half of the participating healthcare Centres have implemented the basic strategies of health promotion, the health profile of the city of Bandung in 2011 only stated $65.64 \%$ adoption rate of clean and healthy behavior by the public and the rate was relatively stagnant for several years. ${ }^{7}$

This study also found that health promotional efforts are dominated by nurses and midwives classified as mid-level health workers. Such observation had also been confirmed by the 2011 Bandung health profile data. ${ }^{7}$ Additionally, a study by Lassi et al. ${ }^{11}$ from 1973-2012 showed that there was no difference in the degree of effectiveness of health service carried out by mid-level health workers and higher level health workers. ${ }^{11}$

Table 3 demonstrates that only 2 health promotional officers have a degree in public health. In 2011, there were only 74 people working at various Puskesmas in Bandung focusing on public health. Health profile data in 2011 also stated that there was only one public health officer for every 3 Puskesmas in Bandung. ${ }^{7}$

Data on table 3 shows that 23 Centres have coordinators on health promotion who previously has undergone training on health promotion and 16 of the coordinators have a certificate on health promotion. Most of these coordinators were either midwives or nurses and this observation was already in accord with the regulations on health promotional officers qualifications. ${ }^{9}$ A study by Yuniarti ${ }^{12}$ stated that the level of education, training, knowledge, skill and leadership capabilities of the officers influenced their performances. ${ }^{12}$ This study has revealed that more than half of the participating coordinators have already fulfilled the criteria on education and training.

From table 3 it can be showed that on the 
Table 4 Health Promotion in Health Facility (1)

\begin{tabular}{|c|c|}
\hline Health Promotion in Health Facility & Number \\
\hline \multicolumn{2}{|l|}{ Registration sites } \\
\hline \multicolumn{2}{|l|}{ Type of information } \\
\hline Service flow & 22 \\
\hline Service type & 18 \\
\hline Map of clinic & 10 \\
\hline Problem info & 16 \\
\hline Regulations & 19 \\
\hline \multicolumn{2}{|l|}{ Media } \\
\hline Leaflet & 11 \\
\hline Poster & 20 \\
\hline Flyers & 13 \\
\hline Other media & 7 \\
\hline \multicolumn{2}{|l|}{ Polyclinic } \\
\hline Interview with officers & 24 \\
\hline \multicolumn{2}{|l|}{ Models } \\
\hline Flipchart & 19 \\
\hline Poster & 14 \\
\hline Leaflet & 21 \\
\hline Pictures & 17 \\
\hline \multicolumn{2}{|l|}{ Polyclinic } \\
\hline \multicolumn{2}{|l|}{ Models } \\
\hline Other media & 7 \\
\hline Information dispersal media in waiting rooms & 24 \\
\hline \multicolumn{2}{|l|}{ Contraception and mother-child health wards } \\
\hline Interview with patients & 24 \\
\hline Health information media & 24 \\
\hline \multicolumn{2}{|l|}{ Inpatient wards } \\
\hline Education & 2 \\
\hline Preventive readings & 2 \\
\hline Group-based health promotion & 1 \\
\hline Media in waiting rooms & 2 \\
\hline \multicolumn{2}{|l|}{ Centre yards } \\
\hline Information on clean and healthy behavior & 21 \\
\hline Family Drug Plants & 16 \\
\hline Health promotion on the walls & 24 \\
\hline National Health Day information & 9 \\
\hline Health information at the canteen & 5 \\
\hline Health information at religious sites & 5 \\
\hline
\end{tabular}


Table 4 Health Promotion in Health Facility (2)

\begin{tabular}{lc}
\hline \multicolumn{1}{c}{ Health Promotion in Health Facility } & Number \\
\hline Laboratories & 11 \\
Health information media & 9 \\
Drug storage rooms & \\
$\quad$ Health information media & 12 \\
Cashiers & \\
Hospitality toward patients & 18 \\
Specialist clinics & \\
Counselling service & \\
\hline
\end{tabular}

one hand, lectures are the preferred method when approaching the groups and the masses. Harsono $^{13}$ lengthily explained that utilizing animations during lectures influenced the effectiveness of the lectures. Thus, health promotional officers should come up with innovations on improving the dispersal of health-related information. On the other hand, guidelines are the least favored method of health promotion.

The collected data demonstrate that mass media dominates health promotion while board medias are the least utilized. From 18 out of 24 participated healthcare Centres used electronic media. According to a study by Pramono ${ }^{14}$, knowledge on clean and healthy behavior (is improved significantly by the use of electronic media. Then, a study by
Rahmawati ${ }^{15}$ in 2007 stated that mothers with young children exhibited better improvements on knowledge and behavior after being taught using audiovisual media than conventional media (e.g., modules). Another study by Sweeney ${ }^{16}$ in 2012 also stated that technology presents an ideal means for healthcare Centrees to improve public health status. Thus, healthcare officers should be familiar in using technology to promote health and better disperse health information.

Table 3 also states that the availability of funds for health promotion-related activities are only found in 13 Centres. Currently, there is no standard on the amount of funds allocated for such activities. ${ }^{9}$ A previous study stated that universal health coverage can only be achieved if the government invests sufficient political

Table 5 Health Promotional Activites in the Community

\begin{tabular}{lc}
\hline \multicolumn{1}{c}{ Health promotion in the community } & Number \\
\hline Performed activities & 24 \\
Individual approach & 23 \\
Family approach & 6 \\
Approach to public organizations & 10 \\
Activities involving the community & 4 \\
Others & \\
Parties involved & 3 \\
Health community personnels & 20 \\
Doctor & 22 \\
Nurse & 22 \\
Midwife & 16 \\
Sanitarian & 14 \\
Others & \\
\hline
\end{tabular}


and monetary support for effective and widereaching programs. ${ }^{17}$ Such recommendation should be implemented in Indonesia, which has only recently adopted a nationwide health insurance, in order to achieve effective health promotion.

Table 4 indicates that out of the 24 participated Centres, health promotion in inpatients wards are practised the least. Such data are explained by the lack of such wards in the Puskesmas. ${ }^{7}$

According to table 5, health promotion in the community focuses on the approaches to individuals and families. Gogia and Sachdev ${ }^{18}$ explained that home visits in the name of antenatal and neonatal care contributed to the reduction in neonatal mortality in Southeast Asia. Besides that, health promotion in the community focuses on the approaches to individuals and families can be the solution of barriers to health care access among elderly. ${ }^{19}$ These further highlight the importance of health promotion in the community.

This study has revealed that at least some form of health promotions had been done in most participating health Centres. The lack of public health officers is tackled by the presence of nurses and midwives who have undergone training and earned certification on health promotion. Limited funds and lack of established guidelines on health promotion form the primary shortcomings of health promotional efforts. The limitation of this study is primarily on the lack of cooperations by the respondents in filling out the questionnaires completely. Furthermore, this study has not gone as far as investigating the quality of the health promotional materials presented both in the healthcare Centres and in the community. Further studies are required to investigate the performance of the health promotional officers.

\section{References}

1. Smith BJ, Tang KC, Nutbeam D. WHO health promotion glossary: new terms. Health Promot Int. 2006;21(4):340-5.

2. Kementerian Kesehatan Republik Indonesia. Keputusan Menteri Kesehatan Republik Indonesia Nomor 128/MENKES/ SK/II/2004 Tentang Kebijakan Dasar Pusat Kesehatan Masyarakat. Jakarta: Kementerian Kesehatan Republik Indonesia; 2004.

3. Kementerian Kesehatan Republik Indonesia. Peraturan Menteri Kesehatan Republik Indonesia Nomor 75 Tahun 2014 tentang Pusat Kesehatan Masyarakat. Jakarta: Kementerian Kesehatan Republik Indonesia; 2014.

4. Howat P, Hallett J, Kypri K, Maycock B, Dhaliwal S, McManus A. Tobacco smoking in an Australian university sample and implications for health promotion. Prev Med. 2010;51(5):425-6.

5. Kementerian Kesehatan Republik Indonesia. Keputusan Menteri Kesehatan Republik Indonesia Nomor 585/MENKES/ SK/V/2007 tentang Pedoman Pelaksanaan Promosi Kesehatan di Puskesmas. Jakarta: Kementerian Kesehatan Republik Indonesia; 2007.

6. Dinas Kesehatan Kota Bandung. Profil Dinas Kesehatan Kota Bandung Tahun 2011. Bandung: Dinas Kesehatan Kota Bandung; 2012.

7. Presiden Republik Indonesia. Peraturan Presiden Republik Indonesia Nomor 12 Tahun 2013 tentang Jaminan Kesehatan. Jakarta: Republik Indonesia; 2013.

8. Hartono B. Promosi kesehatan di Puskesmas dan Rumah Sakit. 1st ed. Jakarta: Rineka Cipta; 2010.

9. Rezeki S, Mulyadi A, Nopriadi. Strategi promosi kesehatan terhadap peningkatan perilaku hidup bersih dan sehat individu pada masyarakat perkebunan di wilayah Puskesmas Sei Kijang Kabupaten Pelalawan. Jurnal Ilmu Lingkungan. 2013;7(1):38-48.

10. Lassi ZS, Cometto G, Huicho L, Bhutta ZA. Quality of care provided by mid-level health workers: systematic review and meta-analysis. Bull World Health Organ. 2013;91(11):824-33I.

11. Yuniarti Y, Shaluhiyah Z, Widjanarko B. Kinerja petugas penyuluh kesehatan masyarakat dalam praktek promosi kesehatan di Dinas Kesehatan Kabupaten Pati. Jurnal Promosi Kesehatan Indonesia. 2012;7(2):165?-73.

12. Harsono B, Soesanto, Samsudi. Perbedaan hasil belajar antara metode ceramah konvensional dengan ceramah berbantuan media animasi pada pembelajaran kompetensi perakitan dan pemasangan sistem rem. Jurnal Pendidikan Teknik Mesin. 2009;9(2):71-9.

13. Pramono MS, Paramita A. Peningkatan pengetahuan anak - anak tentang Perilaku hidup bersih dan sehat, dan penyakit menular melalui teknik KIE berupa permainan elektronik. Buletin Penelitian Sistem Kesehatan. 2011;14(4 Okt):311-9.

14. Rahmawati I, Sudargo T, Paramastri I. 
Pengaruh penyuluhan dengan media audio visual terhadap peningkatan pengetahuan, sikap dan perillaku ibu balita gizi kurang dan buruk di Kabupaten Kotawaringin Barat Provinsi Kalimantan Tengah. Jurnal Gizi Klinik Indonesia. 2007;4(2):1-7

15. Sweeney SA, Bazemore A, Phillips RL Jr, Etz RS, Stange KC. A re-emerging political space for linking person and community through primary health care. Am J Prev Med. 2012;42(6 Suppl 2):S184-90.

16. Coe G, de Beyer J. The imperative for health promotion in universal health coverage. Glob Health Sci Pract. 2014;2(1):10-22.

17. Gogia S, Sachdev HS. Home visits by community health workers to prevent neonatal deaths in developing countries: a systematic review. Bull World Health Organ. 2010;88(9):658-66B.

18. Fitzpatrick AL, Powe NR, Cooper LS, Ives DG, Robbins JA. Barriers to health care access among the elderly and who perceives them. Am J Public Health. 2004;94(10):1788-94. 